\title{
MONITORING SEASONAL PROGRESS OF RICE STUBBLE BURNING IN MAJOR RICE GROWING DISTRICTS OF HARYANA, INDIA, USING MULTIDATE AWiFS DATA
}

\author{
Manoj Yadav*, R. Prawasi, Satyawan Jangra, Pooja Rana, Kiran Kumari, Shyam Lal, K. Jakhar, S. Sharma and R. S. Hooda \\ Haryana Space Applications Centre (HARSAC), \\ C.C.S.H.A.U. Campus, Hisar- 125004, India \\ Email: manojyadav60@rediffmail.com
}

Commission VI, WG VI/4

KEY WORDS: AWiFS, Rice Stubble, Burning, NDVI

\begin{abstract}
:
The present paper describes the methodology and results of assessment of seasonal progress of rice stubble burning for 10 major rice growing districts of Haryana state in India. These 10 districts contribute about 84 per cent of total rice area of the state. As the rice fields are immediately required to be vacated for the sowing of next crop the farmers opt for mechanized harvesting and easy way out of burning the stubbles in the field. Such burning result in release of polluting gases and aerosols. Besides, the heating of the soil kills the useful micro-flora of the soil causing soil degradation. Multi-date AWiFS data from Resourcesat 1 and 2 satellites acquired between October 16, 2013 to November 26, 2013 were used for estimating paddy stubble burning areas at different intervals for the year 2013 crop growing season. In season collected ground truth data using hand held GPS along with field photographs were used to identify paddy stubble burning areas and other land features. Complete enumeration approach and Iterative Self-organizing Data Analysis Technique (ISODATA) unsupervised classifier was used for digital analysis. Normalized Difference Vegetation Index (NDVI) of each date was also used with other spectral bands of temporal images. To improve the classification accuracy the non-agricultural areas were masked out. The area was estimated by computing pixels under the classified image mask. Progress of paddy stubble burning was estimated at different intervals for the year 2013 using available cloud free multi-date IRS-P6 AWiFS data to identify the crucial period when stubbles burning takes place in major area so that preventive measures can be taken to curb the menace.
\end{abstract}

\section{INTRODUCTION}

The burning of crop residues in fields is one of the most significant activities of global biomass burning (excluding biofuels; Streets et. al., 2003), and contributes substantially to air pollution. This is particularly true for the treatment of rice straw in Asian countries, where more than 1.2 million $\mathrm{km}^{2}$ of land is used to grow rice, accounting for $60 \%$ of rice production worldwide. After harvesting, the waste rice straw is frequently burned in the open in regions with insufficient time before planting the next crop to remove and dispose of it in a more controlled manner, such as in a furnace or by using another closed burning technique (Calvo et. al., 2011). Almost 90-95\% of Paddy area in Punjab, Haryana and Western UP is under intensive Rice-Wheat-System (RWS) Ladha, et. al., 2000). RWS in Haryana is mostly concentrated in the north-eastern and north-western part of Yamuna and Ghaggar flood plains occupying 9.16 lac hectares, which is $24.75 \%$ of the total agricultural area of the state (Panigrahy et. al., 2008). Mechanized combine harvesting technologies, which have become common in RWS in India, leave behind large quantities of straw in the field for open burning of residue. The burning of rice residue emits GHG emissions as carbon dioxide $(\mathrm{CO} 2)$, methane $(\mathrm{CH} 4)$, and nitrous oxide $(\mathrm{N} 2 \mathrm{O})$, pollutants as carbon monoxide $(\mathrm{CO})$, particulate matter $(\mathrm{PM})$, and toxic as polycyclic aromatic hydrocarbons (PAHs) due to the incomplete combustion process (P.M. Lemieux et. al., 2004and F. Duan et. al., 2004). The emissions of $\mathrm{CH}_{4}, \mathrm{CO}, \mathrm{N}_{2} \mathrm{O}$, and $\mathrm{NO}_{x}$ have been estimated to be about 110,2306, 2 and $84 \mathrm{Gg}$ respectively, from rice and wheat straw burning in India in the year 2000 (Gupta, et. al., 2004). Residue burning causes nutrient and resource loss and adversely affects soil properties, thus calling for improvement in harvesting technologies and sustainable management of RWS. As per one study nearly 5504 sq. km. of wheat crop area and 12685 sq. $\mathrm{km}$. of rice crop area was burnt during 2005 in Punjab state (Badarinath, et. al., 2006). Burning of crop residue leaves black coloration of the field which can be picked up and assessed by remote sensing. Such attempt has been made for Punjab using course resolution AWiFS satellite data for the year 2005 (Badrinath et.al., 2006). However, they have used a single date satellite data for both the seasons. Techniques of Remote sensing (RS) based crop discrimination and area estimation including single date approach based on maximum likelihood classification as well as hierarchical classification has been developed in India (Dadhwal et, al., 2002). As residue burning and ploughing the fields is a gradual process, all burning areas may not be picked up in the single date imagery. Singh et. al., (2009) investigated the use of multi-sensor characteristics for the accurate assessment of crop residue burnt areas at regular interval for two districts of Punjab. Temporal LISS-III, LISS-IV, MODIS and AVHRR data of pre-burning and post burning stages have been used in the quantitative estimation of burnt areas (Singh et. al., 2009). The multi-temporal image difference technique using three different indices (NDVI, NBR and GEMI3) were used to identify crop stubble burnt areas. Moderate resolution LISS-III data was found to be useful for accurate estimation of burned surface. Area estimation of burnt paddy stubbles for major paddy 
growing districts of Haryana was attempted by Yadav et. al., (2013 \& 2014) using multi-date AWiFS sensor data of Indian satellites. Crop residue discrimination over agricultural fields of Moga and Naraingarh areas of Punjab state of India was attempted by Singh et. al., (2013) using ground- based hyper spectral data. The present study has been attempted for area estimation of paddy stubble burning in ten major paddy growing districts of Haryana, India using multi-date Resourcesat-1 and 2 AWiFS data of Indian Remote Sensing Satellite for the year 2013.

\section{METHODOLOGY}

\subsection{Study Area}

Ten project districts namely Ambala, Fatehabad, Jind, Kaithal, Karnal, Kurukshetra, Panipat, Sirsa, Sonipat, and Yamunanagar situated between $28^{0} 45^{\prime}$ to $30^{\circ} 35^{\prime} \mathrm{N}$ latitudes and $74^{0} 25^{\prime}$ to $77^{\circ} 40^{\prime} \mathrm{E}$ longitudes, were selected for the study as they contribute more then $84 \%$ ) of the paddy stubble burning areas in the state (Figure 1). The geographical area of these ten districts is 1574 , $2538,2702,2317,2520,1530,1268,4277,2122$ and 1768 sq. km. respectively. The project districts have a sub-tropical continental monsoon climate with hot summer and cool winter. The average annual rainfall of districts for the four years 2007-2010 varied between $267 \mathrm{~mm}$ in Western district Sirsa to $964 \mathrm{~mm}$ in most northern district Yamunanagar (State Statistical Abstract of Haryana, 2013). For all the districts wheat is the dominating/major crop during rabi season and paddy is the dominating/major crop during kharif season.

\subsection{Data Used}

\subsubsection{Satellite Data}

Satellite, sensor and acquisition dates for the data used during analysis are given in Table 1.

\begin{tabular}{|l|l|l|}
\hline $\begin{array}{l}\text { Crop of } \\
\text { Study }\end{array}$ & $\begin{array}{c}\text { Satellte \& } \\
\text { Sensor }\end{array}$ & \multicolumn{1}{|c|}{$\begin{array}{c}\text { Date of } \\
\text { Acquisition }\end{array}$} \\
\hline Paddy & Resourcesat- & $16 / 10 / 2013$, \\
& $1 / 2$ AWiFS & $23 / 10 / 2013$, \\
& & $28 / 10 / 2013$, \\
& & $02 / 11 / 2013$, \\
& & $11 / 11 / 2013$, \\
& & $16 / 11 / 2013$, \\
& & $21 / 11 / 2013$, \\
\hline
\end{tabular}

Table 1: IRS Satellite data used in digital analysis

\subsubsection{Collatoral Data}

In season ground truth was collected using the handheld GPS along with the field photographs, twice during second fortnight of October and first fortnight of November, 2013. This ground truth information was used for the identification of the stubble burnt areas of rice, associated crops and land features during digital classification of satellite data.

\subsection{Digital Data Analysis}

Digital image analysis was carried out using Geomatica, ERDAS Imagine and ArcGIS software packages using complete enumeration approach. Details of the steps involved in digital analysis are described elsewhere (Anonymous, 1990 and Patel et al., 1993, Yadav et. al., 2008, Hooda et. al., 2008, Yadav et.al., 2014.

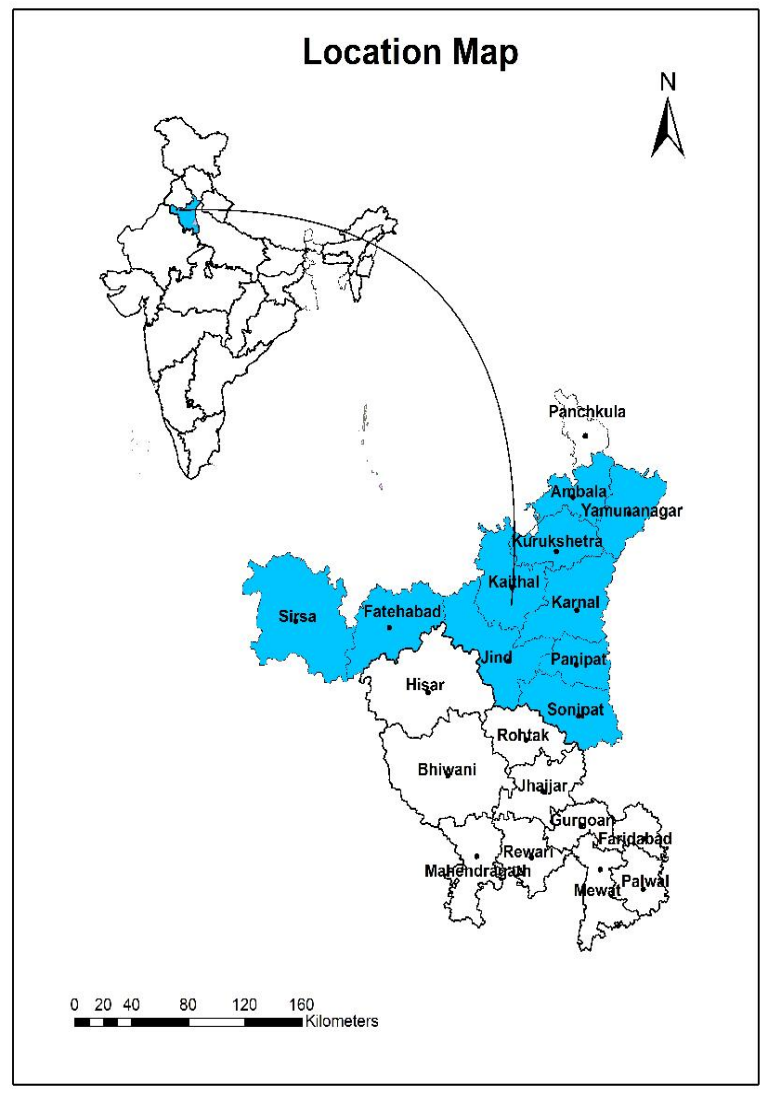

Figure 1. Location Map of Study Districts

This Geo-tiff image data was imported to image format using ERDAS Imagine software package and later on exported to pix format using Geomatica software package. The temporal images prepared were used for digital analysis using complete enumeration approach. In complete enumeration approach the administrative boundary of the project districts were superimposed on the geo-referenced image and all the data elements (pixels) within this were extracted for further classification etc. (Figures 2). Such a procedure has been successfully used for wheat (Dadhwal and Parihar, 1985), (Kalubarme et. al., 2004), rice (Kalubarme \& Vyas, 1990), Oilseeds (Sharma et.al., 1991), Sugarcane (Saroha et.al.,1999), for Saanthi Paddy (Hooda et.al, 2008) and for Burning wheat/paddy stubble (Yadav et. al., 2013 \& 14 ) in the past. Normalized Difference Vegetation Index (NDVI) was computed for each date of satellite data and used during analysis along with spectral bands. NDVI was scaled up by multiplying with 100 and adding 100 to obtain range from 0 to 200 (Panigrahy et. al., 2004). To round off the NDVI values 0.50 was added. The NDVI was computed as follows:

$$
\mathrm{NDVI}=\mathrm{NIR}-\mathrm{R} / \mathrm{NIR}+\mathrm{R} * 100+100+0.5
$$

Unsupervised classification based Iterative Self-organizing Data Analysis Technique (ISODATA) Clustering approach was used and classes of interest were identified using ground truth information and field photographs. To improve the accuracy, mask of non-agricultural classes (Figure 2) and NDVI was generated and used during classification. The burnt stubbles, associated crops and other land features were identified using ground truth data. The mask of mixed classes was prepared and image under the mask was reclassified to segregate the burnt 
stubble from associated land features. A combined mask was prepared from multi phased classified images. The area of the mask out images was classified and per cent burnt stubbles area was computed.

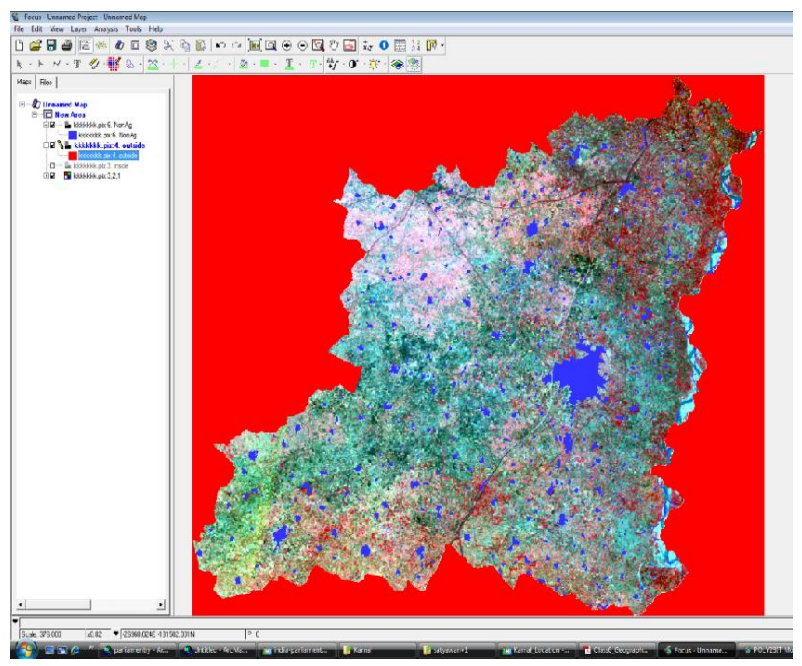

Figure 2. Procedure for AOI extraction and preparation of Nonagricultural mask

\section{RESULTS AND DISCUSSIONS}

Sowing/planting of paddy in Haryana takes place during June to July and harvested during from first fortnight of October to first fortnight of November. As the fields are immediately required for the sowing of next crop the farmers have easy way out to go for burning of stubble in the field. District wise paddy stubble burning area of the districts at different intervals for the year 2013 are given in Table 2, 3 and Spatial distribution of paddy stubble area is depicted in Figures 3 to 10.

Total paddy stubble burning area in the ten project districts during the study period from October 16 to November 26, 2013 was observed to be 208.34 thousand hectares which is $20.29 \%$ of the total paddy cropped area in these districts Study indicates that concentration of burnt paddy stubble area is more in three northern districts i.e. Karnal (54.33 th. ha.), Kaithal (41.42 th. ha.), Kurukshetra (39.82 th. ha.) and one western district of Fatehabad ( 32.68 th. ha.) as compared to other study districts. Concentration of burnt paddy stubble area is moderate in Sirsa (19.61 th. ha.) and Ambala (12.27 th. ha.) districts while in Jind (4.17 th. ha.), Yamunanagar (1.98 th. ha.), Sonipat (1.23 th. ha.) and Panipat ( 0.81 th. ha.) districts very less paddy stubble burning area was observed (Table 4 and Figure 11).

In project districts paddy stubble burning area was recorded (49.04 th. ha.) on October 16 and reached at the peak on October 23 (53.03 th. ha.) and afterwards sowing decreasing trend and reached at negligible level on November 26, 2013 (Table 2 and 3).

Study indicates that early harvesting and burning of paddy stubble takes place in northern districts namely Kaithal, Karnal, Kurukshetra one central district Jind and eastern districts Panipat and Sonipat during second week of October. Harvesting and burning of paddy stubble takes place during first week of November in Northern districts Ambala, Yamunanagar and central district Fatehabad. Late harvesting and burning takes place in Sirsa district during $3^{\text {rd }}$ week of November (Figure 3 to 10).

\begin{tabular}{|c|c|c|c|c|c|}
\hline \multirow{2}{*}{$\begin{array}{l}\text { Sr. } \\
\text { No. }\end{array}$} & \multirow{2}{*}{$\begin{array}{l}\text { District/ } \\
\text { Parameter }\end{array}$} & \multicolumn{4}{|c|}{ Stubble Burning Area '000 ha. } \\
\hline & & $\begin{array}{l}16-10- \\
2013\end{array}$ & $\begin{array}{l}23-10- \\
2013\end{array}$ & $\begin{array}{l}28-10- \\
2013\end{array}$ & $\begin{array}{l}2-11- \\
2013\end{array}$ \\
\hline 1 & Ambala & 2.13 & 1.00 & 1.39 & 7.72 \\
\hline 2 & $\mathrm{~F} / \mathrm{Bad}$ & 0.94 & 3.02 & 7.91 & 10.76 \\
\hline 3 & Jind & 0.34 & 0.38 & 1.85 & 1.05 \\
\hline 4 & Kaithal & 13.6 & 13.63 & 12.21 & 1.74 \\
\hline 5 & Karnal & 19.19 & 22.04 & 11.57 & 1.26 \\
\hline 6 & $\mathrm{~K} /$ Shetra & 11.91 & 11.72 & 14.91 & 1.17 \\
\hline 7 & Panipat & 0.16 & 0.22 & 0.23 & 0.04 \\
\hline 8 & Sirsa & 0.02 & 0.19 & 1.84 & 1.94 \\
\hline 9 & Sonipat & 0.01 & 0.1 & 0.14 & 0.00 \\
\hline 10 & Y/Nagar & 0.12 & 0.09 & 0.16 & 1.60 \\
\hline & Total & 49.1 & 53.03 & 52.52 & 26.55 \\
\hline
\end{tabular}

Table 2. Paddy Stubble Burning Area In Districts of Haryana at Different Intervals

\begin{tabular}{|r|l|r|r|r|r|}
\hline \multicolumn{1}{l|}{$\begin{array}{r}\text { Sr. } \\
\text { No. }\end{array}$} & District/ & \multicolumn{5}{|c|}{ Parameter } \\
\cline { 3 - 6 } & & $\begin{array}{l}11-11- \\
2013\end{array}$ & $\begin{array}{l}16-11- \\
2013\end{array}$ & $\begin{array}{l}21-11- \\
2013\end{array}$ & \multicolumn{1}{|c|}{$\begin{array}{l}26-11- \\
2013\end{array}$} \\
\hline 1 & Ambala & 0.003 & 0.008 & 0.009 & 0 \\
\hline 2 & F/Bad & 5.604 & 4.129 & 0.298 & 0.012 \\
\hline 3 & Jind & 0.428 & 0.115 & 0.004 & 0.002 \\
\hline 4 & Kaithal & 0.207 & 0.031 & 0.002 & 0.001 \\
\hline 5 & Karnal & 0.173 & 0.089 & 0.007 & 0.001 \\
\hline 6 & K/Shetra & 0.083 & 0.036 & 0.003 & 0 \\
\hline 7 & Panipat & 0.003 & 0.16 & 0.002 & 0.002 \\
\hline 8 & Sirsa & 3.923 & 10.263 & 1.038 & 0.394 \\
\hline 9 & Sonipat & 0.013 & 0.938 & 0.015 & 0.009 \\
\hline 10 & Y/Nagar & 0.003 & 0.003 & 0.009 & 0 \\
\hline & Total & 10.151 & 15.232 & 1.351 & 0.409 \\
\hline
\end{tabular}

Table 3. Paddy Stubble Burning Area In Districts of Haryana at Different Intervals

The area estimates are based on the available satellite data and the burnt rice stubble area available on the image between October 16 to November 26, 2013. As the satellite data of paddy harvesting season were not available between October 01 to 14 and November 02 to 11,2013 due to cloudy conditions, it may be possible that the paddy stubble burning area of the period may have been re-sown for rabi crops and not picked on the satellite images. Therefore, we apprehend slight underestimation of the paddy stubble burning area in the study. 


\begin{tabular}{|c|c|c|c|c|}
\hline \multirow{2}{*}{$\begin{array}{l}\text { Sr. } \\
\text { No. }\end{array}$} & \multirow{2}{*}{$\begin{array}{l}\text { District/ } \\
\text { Parameter }\end{array}$} & \multirow{2}{*}{$\begin{array}{l}\text { Paddy } \\
\text { Area } \\
(2013)^{*}\end{array}$} & \multicolumn{2}{|c|}{$16-10-2013$ to $26-11-13$} \\
\hline & & & $\begin{array}{l}\text { Stubble } \\
\text { Burning } \\
\text { Area } \\
\text { ' } 000 \text { ha. }\end{array}$ & $\begin{array}{l}\% \text { of } \\
\text { Paddy } \\
\text { Area }\end{array}$ \\
\hline 1 & Ambala & 79 & 12.27 & 15.53 \\
\hline 2 & $\mathrm{~F} / \mathrm{Bad}$ & 93 & 32.68 & 35.14 \\
\hline 3 & Jind & 118 & 4.17 & 3.53 \\
\hline 4 & Kaithal & 158 & 41.42 & 26.22 \\
\hline 5 & Karnal & 162 & 54.33 & 33.54 \\
\hline$\overline{6}$ & $\mathrm{~K} /$ Shetra & 118 & 39.82 & 33.75 \\
\hline 7 & Panipat & 62 & 0.81 & 1.31 \\
\hline 8 & Sirsa & 68 & 19.61 & 28.84 \\
\hline$\overline{9}$ & Sonipat & 100 & 1.23 & 1.23 \\
\hline 10 & Y/Nagar & 69 & 1.98 & 2.87 \\
\hline & Total & 1027 & 208.34 & 20.29 \\
\hline
\end{tabular}

Table 4. Paddy Stubble Burning Area In Districts of Haryana for Total Study Period

*Department of Agriculture, Haryana

\section{CONCLUSIONS}

It was observed that in season multi-date LISS-3 data is useful for the acreage estimation of burnt paddy stubble at district level. In the present study due to non availability of multi-date cloud free LISS-III digital data, in season multi-date AWiFS data was were used. The data were found to be useful due to its better temporal resolution. Resourcesat $1 \& 2 \mathrm{AWiFS}$ with short wave infra-wave along with NDVI of all dates provided separability of paddy stubble burnt areas. For a small state like Haryana complete enumeration approach is useful to improve accuracy along with masks of non agricultural classes such as water bodies, settlement, forest, plantation and wastelands etc. In season temporal AWiFS data between October 16, 2013 to November 26, 2013 are found to be useful for the study.

Total paddy stubble burnt area in the ten project districts was observed to be 208.34 thousand hectares. Study indicates that extent of burnt paddy stubble area is more in three northern districts of Karnal (54.33 th. ha.), Kaithal (41.42 th. ha.), Kurukshetra (39.82 th. ha.), and one western district i.e. Fatehabad (32.68 th. ha.), moderate in Sirsa (19.61 th. ha.) and Ambala (12.27 th. ha.) districts while in Jind (4.17 th. ha.), Yamunanagar (1.98 th. ha.), Sonipat (1.23 th. ha.) and Panipat (0.81 th. ha.) districts very less paddy stubbles burning was observed. Low paddy stubble burning in Jind, Yamunanagar, Sonipat and Panipat districts may be due to manual harvesting and low land holding.

In project districts paddy stubble burning area was recorded (49.04 th. ha.) on October 16 and reached at the peak on October 23 (53.03 th. ha.) and afterwards sowing decreasing trend and reached at negligible level on November 26, 2013. Study indicates that early harvesting and burning of paddy stubble takes place in northern districts namely Kaithal, Karnal, Kurukshetra one central district Jind and eastern districts Panipat and Sonipat during second week of October. Harvesting and burning of paddy stubble takes place during first week of November in Northern districts Ambala, Yamunanagar and central district Fatehabad. Late harvesting and burning takes place in Sirsa district during $3^{\text {rd }}$ week of November.

As the satellite data of paddy harvesting season are not available between October 01 to 14 and November 02 to 11,2013 due to cloudy conditions, it may be possible that the burnt area of the period may be resown for rabi crops and not picked on the satellite images of the later date. Consequently there could be little under estimation in paddy stubbles burnt area progress of paddy stubble burning takes place during the period was not monitored. More frequent satellite data availability is required for such studies. Regular monitoring of paddy stubble burning area using satellite data is required for controlling the menace of crop stubble burning in open fields and to monitor the effect of campaign against the dangerous practice.

\section{ACKNOWLEDGEMENTS}

Authors are thankful to Haryana State Pollution Control Board (HSPCB), Panchkula, Haryana for taking keen interest and providing financial assistance for the project. We would like to place on records the heartfelt thanks to Agriculture Department, Haryana for providing crop related information and for extending all possible help during ground truth collection. Help provided by other staff members of HARSAC is also thankfully acknowledged.

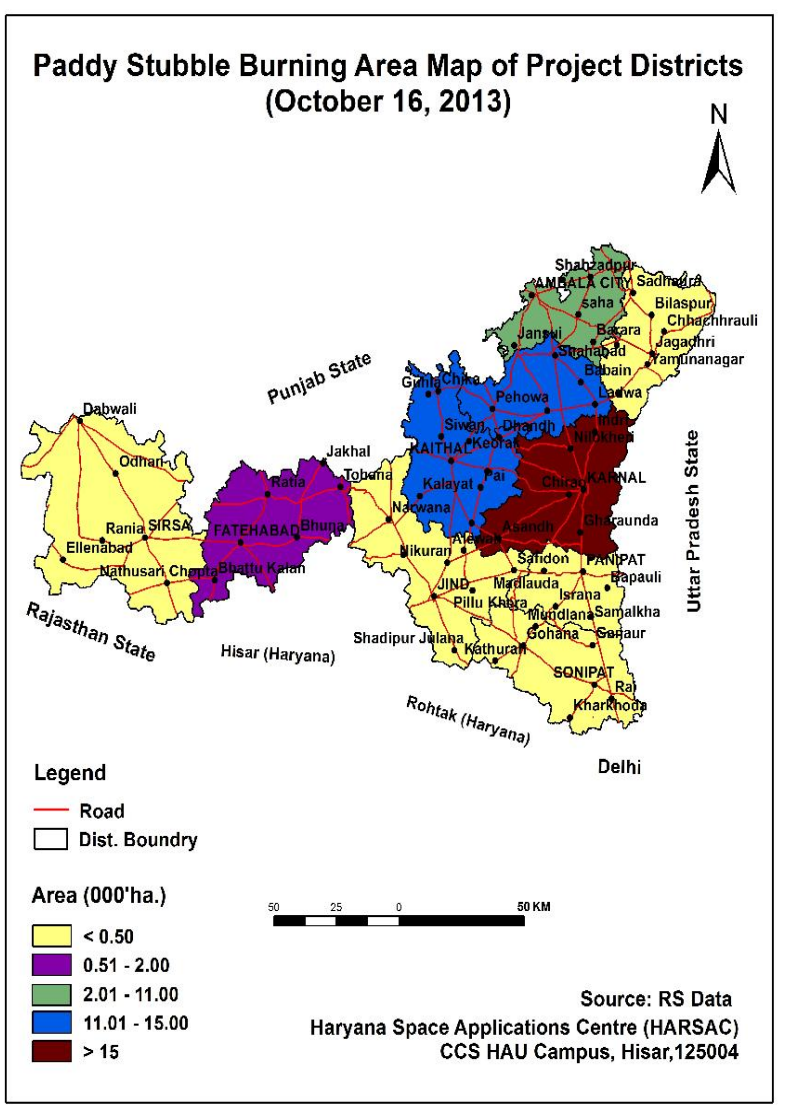

Figure 3. Paddy Stubble Burning Area Map 


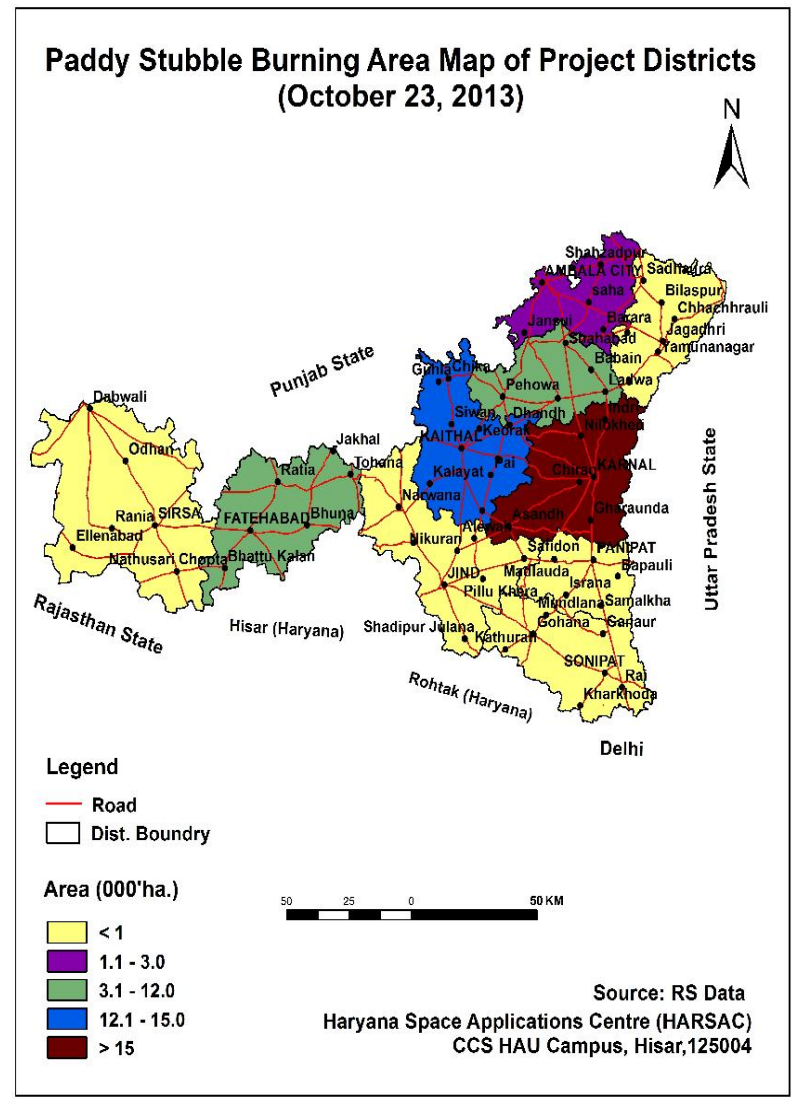

Figure 4. Paddy Stubble Burning Area Map

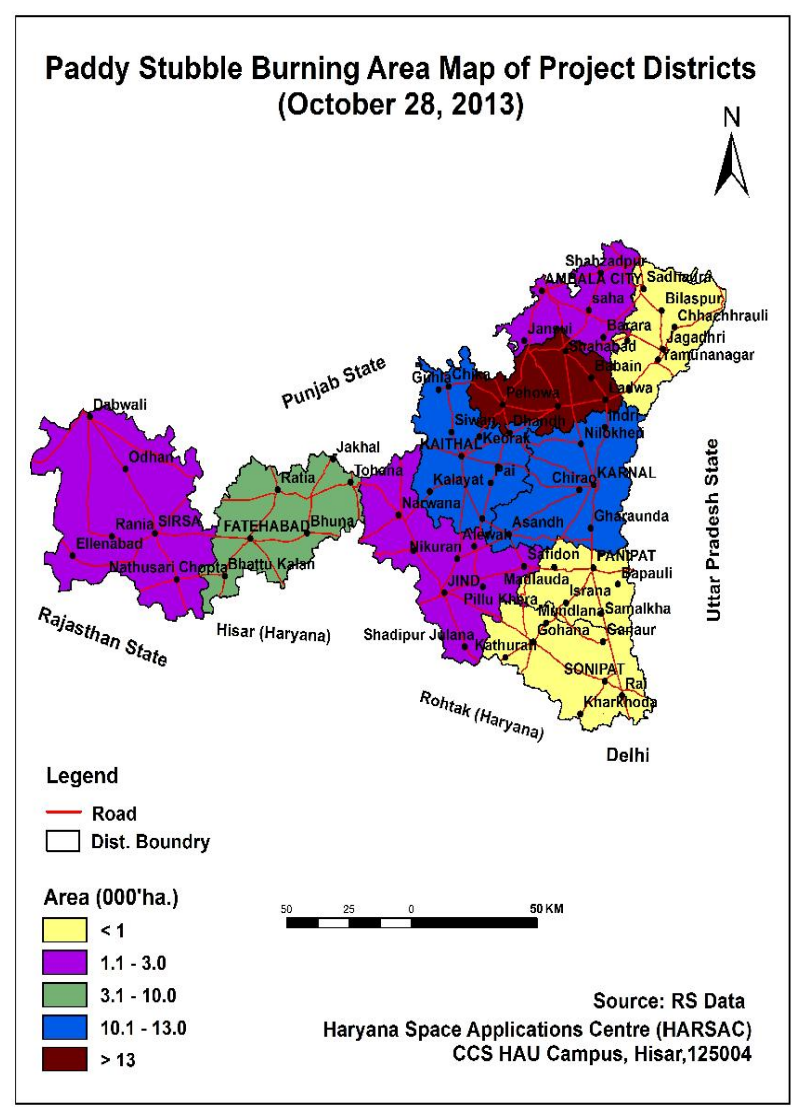

Figure 5. Paddy Stubble Burning Area Map

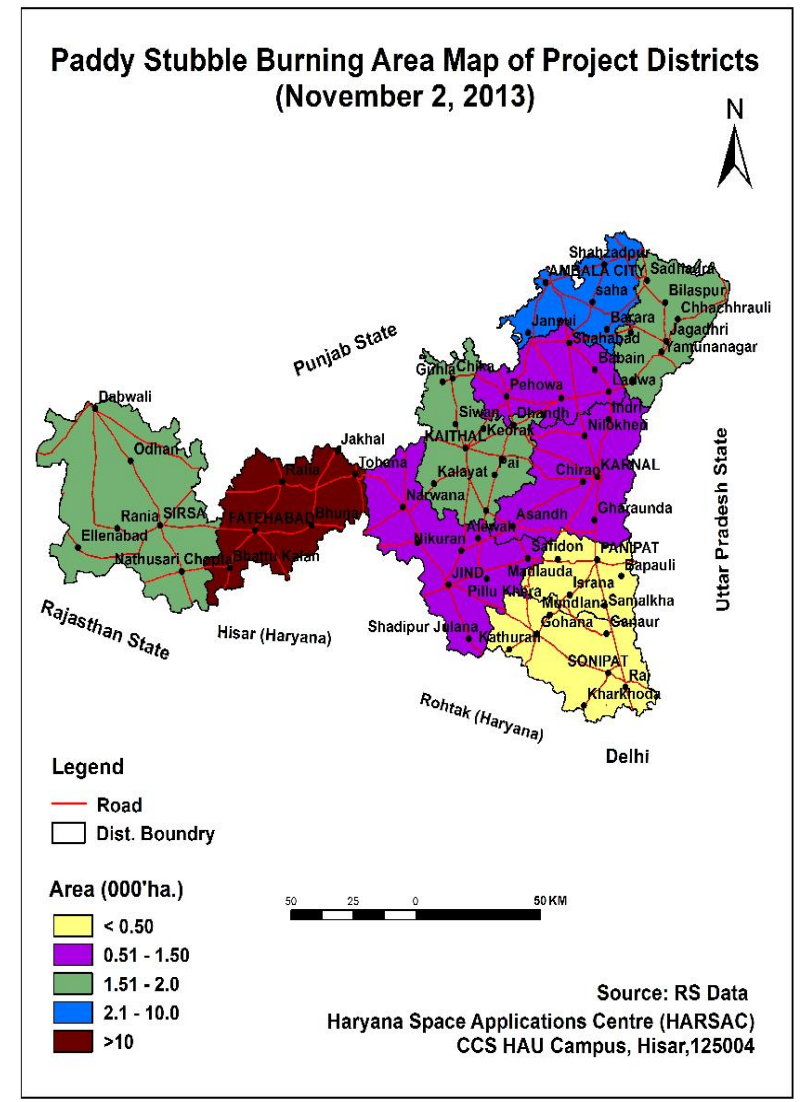

Figure 6. Paddy Stubble Burning Area Map

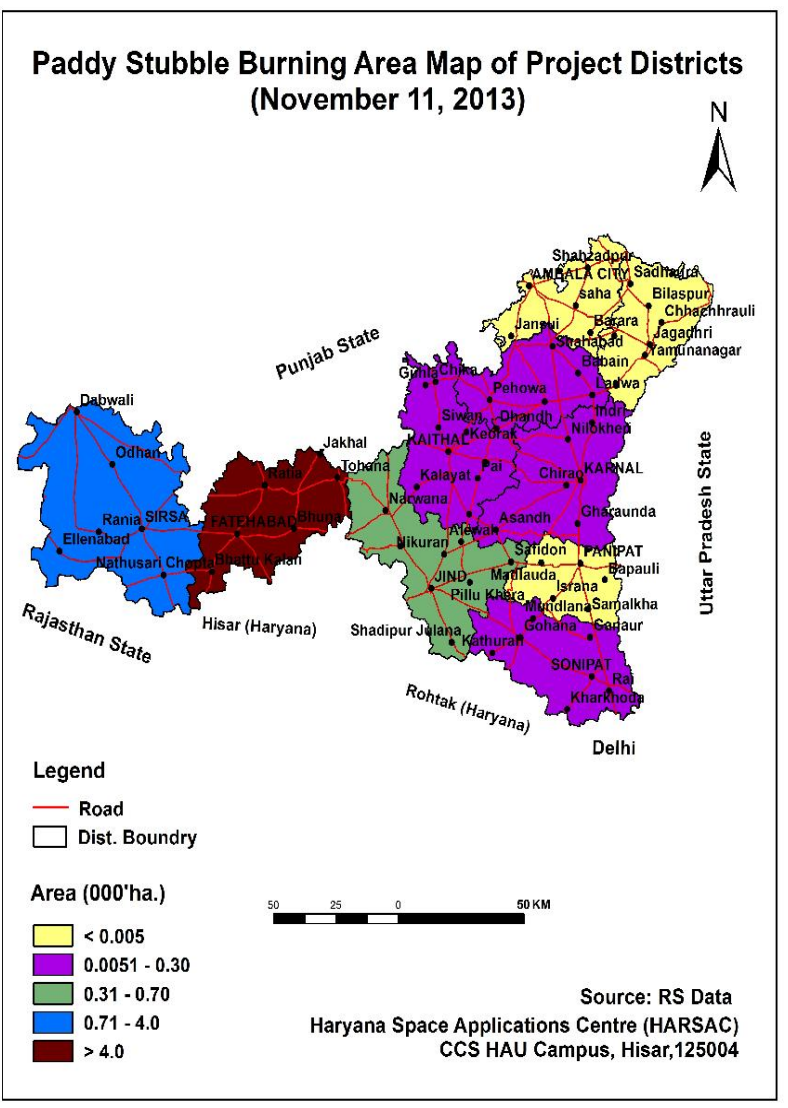

Figure 7. Paddy Stubble Burning Area Map 


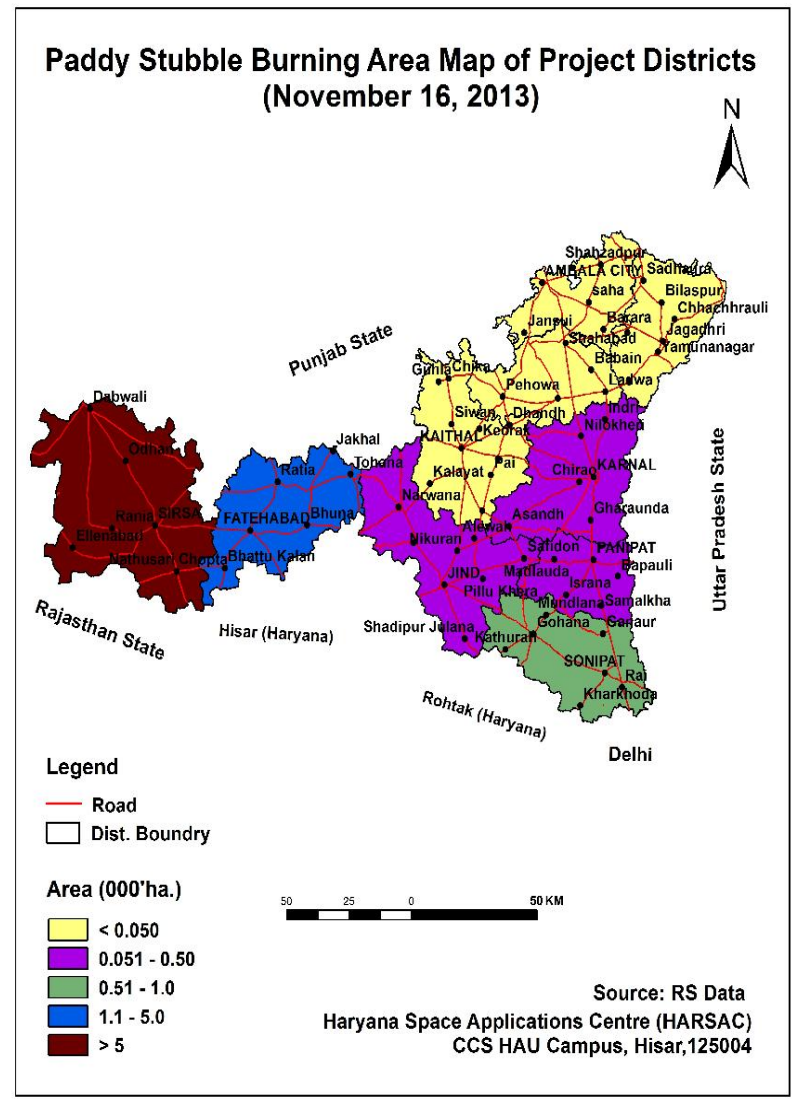

Figure 8. Paddy Stubble Burning Area Map

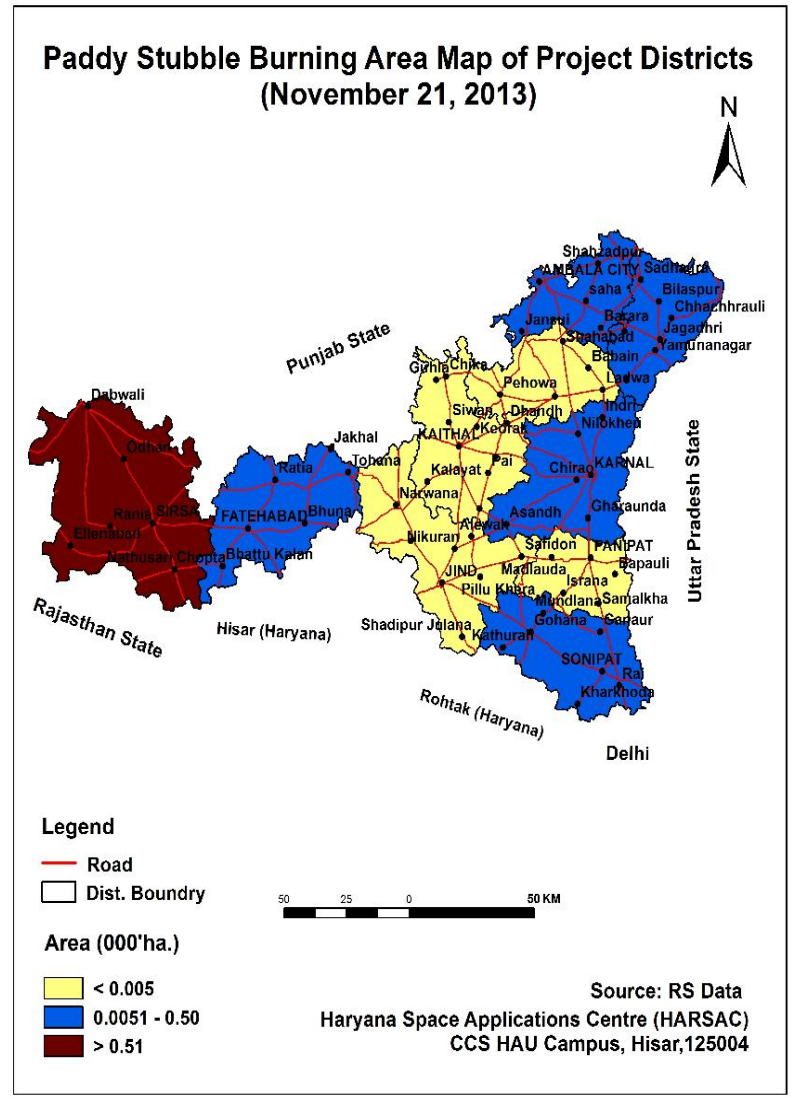

Figure 9. Paddy Stubble Burning Area Map

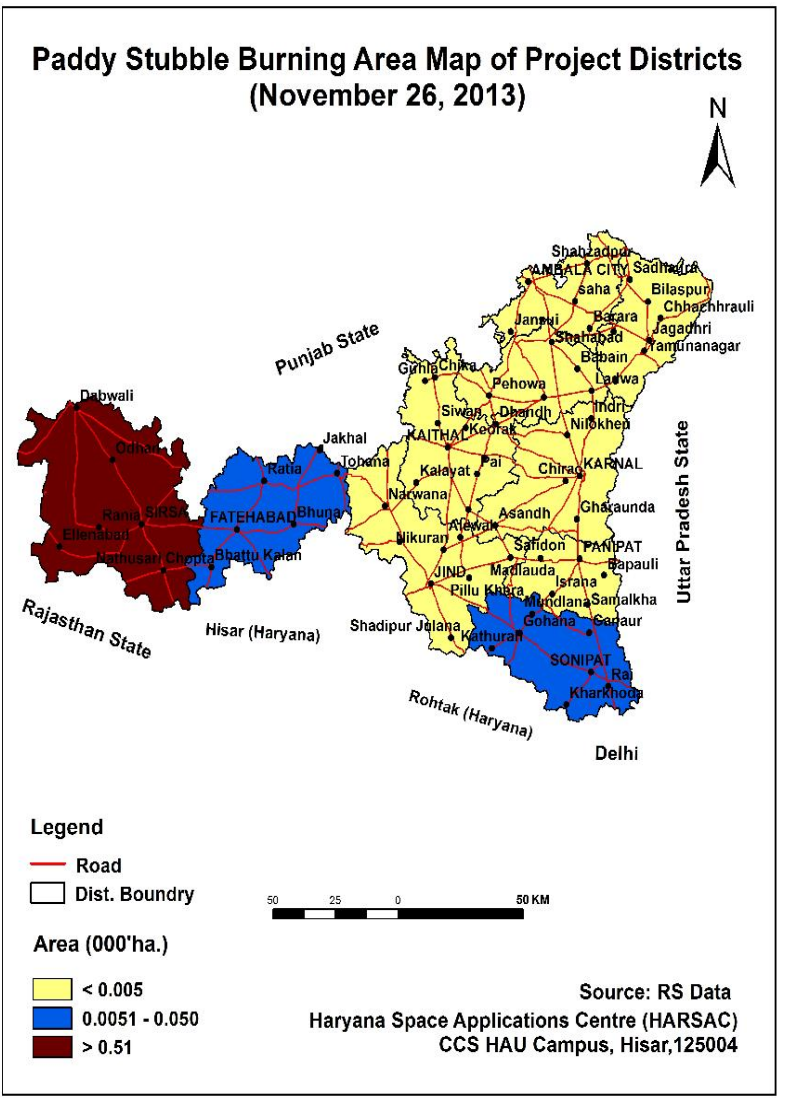

Figure 10. Paddy Stubble Burning Area Map

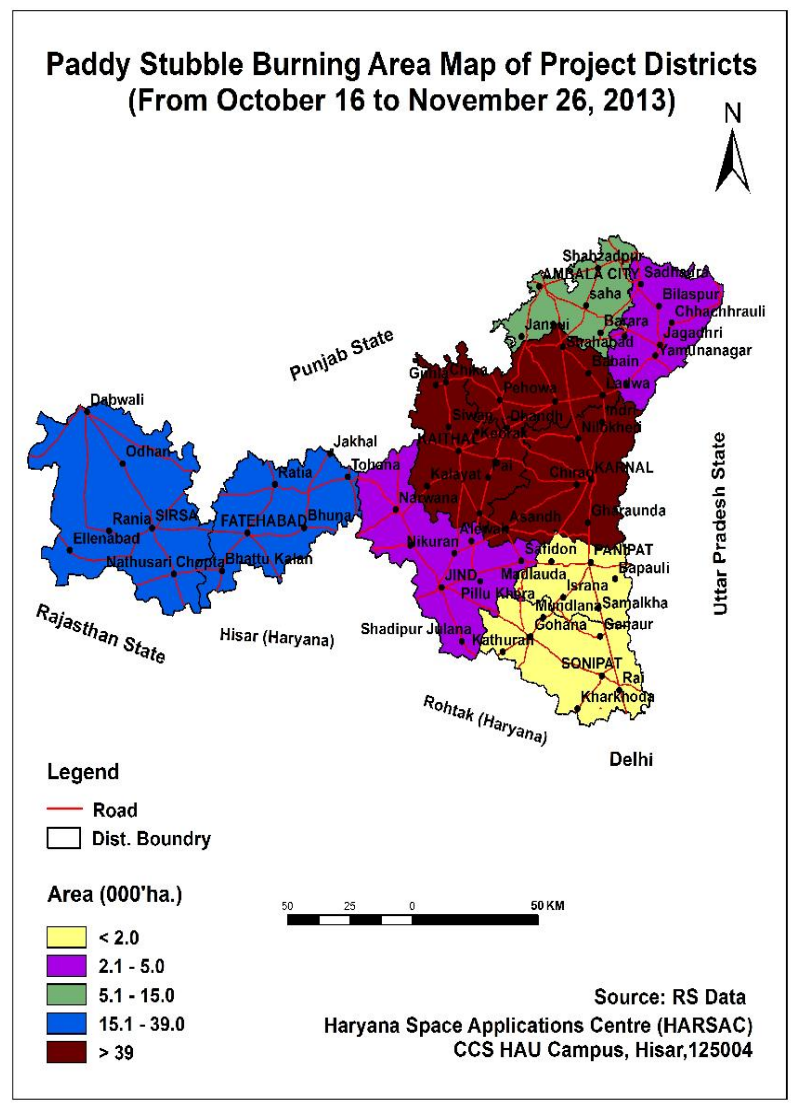

Figure 11. Paddy Stubble Burning Area Map 


\section{REFERENCES}

Anonymous., 1990. Steps in digital image analysis for crop acreage estimation at regional remote sensing service centers, Status report on crop acreage and production estimation, RSAM/SAC/CAPE/SR/25/90, p.239.

Badarinath, K.V.S., T. R. Kiranchand and Krishna Prasad, V., 2006. Agriculture crop residue burning in ht Indo-Gangetic Plains - A study using IRS-P6 AWiFS satellite data. Current Science 91(8), pp. 1085-1089.

Calvo, A. I., Castro, A., Pont, V., Cuetos, M. J., M. E. Sanchez and Fraile, R., 2011. Aerosol Size Distribution and Gaseous Products from the Oven-controlled Combustion of Straw Materials. Aerosol Air Qual. Res. 11, pp. 616-629.

Dadhwal, V. K. and Parihar, J. S., 1985. Estimation of 1983-84 wheat acreage of Karnal district (Haryana) using Landsat MSS digital data. Scientific Note: IRS-UP/SAC/CPF/SN/09/85.

Duan, F., Liu, X., T. Yu and Cachier, H., 2004. Identification and estimate of biomass burning contribution to the urban aerosal organic carbon concentrations in Beijing," Atmospheric Environment 38, pp. 1275- 1282.

Gupta, P. K., Sahai, S., Singh, N., Dixit, C. K., Singh, D. P., Sharma, C., Tiwari, M. K., R. K. Gupta and Garg, S.C., 2004. Residue burning in rice-wheat cropping system: Causes and implications. Current Science 87(12), pp. 1713-1717.

Hooda, R. S., Yadav, M. Sharma, M. P. and Prawasi, R., 2008. Estimation of summer paddy in Haryana (India) using high resolution satellite data. Proc. of International Workshop on Earth Observation \& Remote Sensing Applications, China, January 2225, 2008.

Kalubarme, M. H. and Vyas, S. P., 1990. Remote sensing based rice acreage estimation in Midnapore district (West Bengal). Status Report on CAPE, RSAM/SAC/CAPE/SR/25/90, 178-188 pp.

Kalubarme, M. H., Sharma Alka, Sood R. K., Thapa R., Deol S. S., Negi Kalpana, Sharma Priyanka and Ghabru, S. K., 2004. Wheat production forecast in Himachal Pradesh. Scientific Note: RSAM/SAC/CAPE-II/SN/93/2004.

Ladha, J. K., Fischer, K. S., Hossain, M., P. R. Hobbs and Hardy, B., 2000. Improving the productivity and sustainability of ricewheat systems of the Indo-Gangetic plains: A synthesis of NARSIRRI partnership research. IRRI Discussion Paper Ser. 40, IRRI, Los Banos, Philippines.

Panigrahy, R. K., Ray, S. S. and Panigrahy, S., 2004. Utility of SWIR band for crop discrimination \& classification using single date and Multidate IRS-P6 AWiFS data. Scientific Report: SAC/RESIPA/SR-02.

Panigrahy Sushma, Hooda R. S., Ray S. S., Yadav Manoj, Manjunath K. R., Sharma M. P., Upadhyay Gargi, Kumar M., Panigrahy R. K. and Miglani, Anshu., 2008. Cropping system analysis using remote sensing \& GIS: Haryana state. Technical Report:EOAM/SAC/CS/SN/02/2008.

Patel, N. K., Medhavy, T. T., Hussein, A., Sarangi, B. K. and R. Mohanty, R., 1993. Rice production forecasting for Orissa during 1992-93 kharif season using remote sensing data. Scientific Note : RSAM/SAC/CAPE-II/SN/15/93.
Lemieux, P.M., C. C. Lutes and Santoianni, D. A., 2004. Emissions of organicair toxics from open burning: a comprehensive review, Progress in Energy and Combustion Science 30(1), pp.1-32.

Sharma, S, A., Bhatt, H. P., Ajai and Nanavaty, S., 1991. Rapeseed Mustard acreage estimation using IRS LISS-II data. Photonirvachak 19(1), pp. 59-65.

Singh, G., Y. Kant and Dadhwal, V. K., 2009. Remote sensing of crop residue burning in Punjab (India): A study on burned area estimation using mulyi-sensor approach. Geocarto International 24 (4), pp. 273-292.

Statistical Abstract, Haryana 2011-12., 2013. Published by Economic \& Statistical Advisor, Planning Department, Govt. of Haryana, pp 563.

Streets, D. G., Yarber, K.F., J. H. Woo, and Carmichael, G. R., 2003. Biomass Burning in Asia: Annual and Seasonal Estimates and Atmospheric Emissions. Global Biogeochem. Cycles 17, pp. 1099-1119.

Saroha, G. P., Yadav Manoj, Sharma M. P. and Singh, A., 1999. Sugarcane acreage estimation and monitoring using remote sensing and GIS techniques. Technical Report : HARSAC/TR/13/1999.

Yadav Manoj., Sharma, M. P., Prawasi, R., S. K. Sharma and Hooda, R. S., 2008. Monitoring area under santhi (summer) paddy in Haryana using high resolution satellite data. Bull. of the National Natural Resources Management System (NNRMS) 32, pp. 15-21.

Yadav Manoj., Sharma, M. P., Prawasi, R., Rajeev, Kumar Pawan, Mandal, V. P., Abdul Salim and Hooda R. S., 2014. Estimation of wheat/rice residue burning areas in major districts of Haryana, India using remote sensing data. J. Indian Soc. of Remote Sensing 42 (2), pp. 343-352.

Yadav Manoj, Prawasi, R., Satyawan, Rana Pooja, Kumari Kiran, Lal Shyam, Karamdeep, Siddarth and Hooda, R. S., 2014. Area Estimation of Paddy Stubble Burning in Ten major Paddy Growing of Haryana. Technical Report: HARSAC/TR/01/2014, $28 \mathrm{pp}$. 